\title{
Introduction: Burdens and Beginnings: Rebuilding East and West Germany after Nazism
}

\author{
Karen Hagemann, Konrad H. Jarausch and Tobias Hof ${ }^{1}$
}

\begin{abstract}
The introduction discusses the state of the current research on the post-1945 history of East and West Germany, explains the agenda of the special issue and discusses its main topics. The focus is the politics of survival in the chaos of collapse and the controversial debates about the agenda of the reconstruction. In these discussions different visions competed, from the restoration of traditions to efforts of a post-fascist modernization. The introduction questions the postwar success narrative by discussing the "burdens" of the Nazi past, such as Nazi perpetrators, displaced people, expellees and refugees, including the returning German-Jewish survivors. It also engages with the problems of the Cold War division by exploring the "new beginnings", which were debated in relation to the past of Nazi, Weimar, and Imperial Germany, among them: cultural diplomacy, welfare policy and eldercare, family policy and gender roles, and popular culture. The essay calls for more comparative and transnational research of the postwar era, especially in the areas of the integration into the Cold War blocs, the postwar shifting of borders and peoples, narratives of victimhood, and memory tropes about the war and postwar.
\end{abstract}

Die Einleitung diskutiert den aktuellen Forschungsstand zur Geschichte Ost- und Westdeutschlands nach 1945 und erläutert Zielsetzung und Schwerpunkte des Themenheftes. Im Zentrum stehen die Überlebensstrategien im Chaos des Zusammenbruchs und die zeitgenössischen Debatten über die Agenda des Wiederaufbaus, in denen verschiedene Visionen konkurrierten, die von der Wiederherstellung der Tradition bis zu einer postfaschistischen Modernisierung reichten. Die Einleitung hinterfragt das Narrativ eines erfolgreichen Wiederaufbaus in der Nachkriegszeit durch eine Thematisierung der „Lasten“ der NS Vergangenheit wie nationalsozialistische Täter und Täterinnen, Displaced Persons, Vertriebene und Flüchtlinge, einschließlich der zurückkehrenden deutsch-jüdischen Überlebenden. Zudem thematisiert die Einleitung die Probleme der Spaltung im Kalten Krieg und nimmt die „Neuanfänge“ in den Blick, deren Debatte immer auch auf die Vergangenheit im Nationalsozialismus, der Weimarer Republik und des Kaiserreiches bezogen waren. Dies betraf so verschiedene Bereiche wie kulturelle Diplomatie, Wohlfahrtspolitik und Altenpflege, Familienpolitik und Geschlechterrollen sowie Populärkultur. Der Essay fordert mehr vergleichende und transnationale Forschungen zur Nachkriegszeit, mit einem Fokus auf der trotz der Spaltung in zwei Blöcke bestehenden Interaktion und Verflechtung während des Kalten Krieges, den Verschiebungen von Grenzen und Völkern, sowie den Opfernarrativen und Erinnerungstropen.

$\mathrm{T}$ HE end of the Second World War was a crucial turning point for twentieth-century Germany because the Allies' defeat of the Third Reich fundamentally changed the course of its history. Whereas the first half of the century was marked by the terrors of the First World War, hyperinflation, depression, dictatorship, and the Second World War, its

\footnotetext{
${ }^{1}$ We would like to thank Derek Holmgren for his help with the editing of the whole special issue and the two readers of all manuscripts of this special issue for their constructive feedback.
} 
second half witnessed a more benign development with peace and growing economic, political, and social stability on both sides of the Iron Curtain, even if the beginning was difficult and the Cold War continued to constrain many lives. In spite of Germany's division into two successor states in 1949, the period since the end of the Second World War has remained peaceful. In the western part, a democratic regime evolved with the Federal Republic of Germany (FRG), prosperity expanded, a welfare state emerged, a strong civil society developed, and cultural life flourished. In the eastern part of the country, the "welfare dictatorship" of the German Democratic Republic (GDR) formed, which offered less political freedom, but permitted those citizens who were willing to tolerate or to support the communist regime to live under secure economic and social conditions as well. And finally, with the overthrow of communism, a chastened national state reemerged with a reunited Germany in 1990. In these contrasting stories, the end of the war and immediate postwar period served as a crucial transition phase that initiated a different trajectory. ${ }^{2}$

The rebuilding of the FRG after the Second World War is often portrayed as a success story in the official narratives of West Germany and the United States, which is contrasted to the failed development in the GDR. This interpretation is informed by Cold War ideology. It contains significant gaps, oversimplifies historical development, and overlooks the complexity of the transition from Nazism and war to peace and relative prosperity on both sides of the Iron Curtain. A success narrative neglects the "burdens" of the Nazi past and its long-lasting impact on the two German states. Moreover, it does not sufficiently engage with the problems caused by the Cold War division of Germany and Europe, and the many conflicts in both states over different paths for a new "beginning." Such a view ignores, for instance, the opposition to the mainstream policy in each German state: In the FRG, the left, especially the Communist Party of Germany (Kommunistische Partei Deutschlands, KPD) and the Social Democratic Party (Sozialdemokratische Partei Deutschlands, SPD), rejected the conservative domestic politics and the rapprochement with the West by Chancellor Konrad Adenauer of the Christian Democratic Union (Christlich Demokratische Union, CDU). In the GDR, mainly the Christian-democratic and conservative forces, represented by the Protestant and Catholic Churches and their cultural milieus, opposed the policy of a centralization and monopolization pursued by the Socialist Unity Party (Sozialistische Einheitspartei Deutschlands, SED). But also many former social democrats inside and outside of the SED, created in April 1946 by a compulsory fusion of the KPD and SPD, resisted its communist course shaped by the Soviet Union.

Much of the scholarship before 1990 dealt with either the FRG or the GDR largely ignoring the other state. It explored the post-1945 history with a focus on differences, but not similarities and interrelationships. The unexpected German reunification should have liberated research from this intellectual framework, but the full implications of this transformation have yet to be felt. Since the early 1990s, it has become possible to look more closely at similarities and entanglements between both German states and societies during the period of division and compare and relate their histories. But how should historians write such a comparative and entangled history? Should they highlight the parallels and the similarities of the two German regimes, at least until the SED isolated itself after building the Berlin

\footnotetext{
${ }^{2}$ For overviews see also the following, Konrad H. Jarausch, After Hitler: Recivilizing Germans, 1945-1995 (Oxford: Oxford University Press, 2006); Ulrich Herbert, Geschichte Deutschlands im 20. Jahrhundert (Munich: Beck, 2014), part IV.
} 
Wall in 1961? Should differences be the dominant lenses for examining the history of the two Germanys? Or do both similarities and differences need to be explored? The shared history of the two states and societies until 1945, and the renewal of connections between East and West after 1990, suggest that such a reframing is overdue.

Already in 1993, Christoph Kleßmann proposed that scholars understand the relation between the two German states and societies as one of "entanglement and demarcation" (Verflechtung und Abgrenzung). But research that systematically explores post-1945 German history in this manner is still rare. ${ }^{3}$ One of the first fields for such an approach was the study of the ways in which both German states and societies dealt with and remembered the Nazi past, the Holocaust, and World War II. Jeffrey Herf's 1997 monograph Divided Memory: The Nazi Past in the Two Germanys proved groundbreaking. ${ }^{4}$ The book studied the legacy of the Nazi regime, exposing the workings of past beliefs and political interests and showing how differently the two Germanys recalled the crimes of Nazism, from the anti-Nazi emigration of the 1930s through the establishment of a day of remembrance for the victims of National Socialism in 1996. Several other publications also studied how both German states, societies, and cultures attempted to come to terms with the recent past. More recent research compares the history of German memories of World War II with that of other European states. ${ }^{5}$

Another early area of scholarship that looked at the entangled German history was research on the immediate postwar period in the four German occupations zones. Here, Paul Steege's 2007 study Black Market, Cold War: Everyday Life in Berlin, 1946-1949 and Richard Bessel's 2009 monograph Germany 1945: From War to Peace were trendsetting for works that looked at entangled histories. ${ }^{6}$ Konrad Jarausch, with his After Hitler: Recivilizing Germans, 1945-1995, published in 2006, was one of the first historians who attempted to write a truly integrated historical overview of the two German states after World War II. ${ }^{7}$ Others followed, but mostly focused on a shorter time period or a specific region or subject.

One particularly interesting example is Edith Sheffer's 2011 monograph, Burned Bridge: How East and West Germans Made the Iron Curtain, which investigated hidden origins of the

\footnotetext{
${ }^{3}$ Christoph Kleßmann, "Verflechtung und Abgrenzung. Aspekte der geteilten und zusammengehörigen deutschen Nachkriegsgeschichte," Aus Politik und Zeitgeschichte B 29-30 (1993): 30-41; see also his The Divided Past: Rewriting Post-War German History (Oxford: Berg Publishers, 2001).

${ }^{4}$ Jeffrey Herf, Divided Memory: The Nazi Past in the Two Germanys (Cambridge, MA: Harvard University Press, 1997).

${ }^{5}$ See, for example, Frank Biess, Hanna Schissler, and Mark Roseman, eds., Conflict, Continuity, and Catastrophe in Modern Germany (New York: Berghahn Books, 2007); in a comparative European perspective, Jürgen Zimmerer, ed., Verschweigen-Erinnern-Bewältigen: Vergangenheitspolitik nach 1945 in globaler Perspektive (Leipzig: Leipziger Universitäts Verlag 2004); Helmut Peitsch, Charles Burdett, and Claire Gorrara, eds., European Memories of the Second World War (New York: Berghahn Books, 2006); Monica Riera and Gavin Schaffer, The Lasting War: Society and Identity in Britain, France and Germany after 1945 (Basingstoke: Palgrave Macmillan, 2008); Frank Biess and Robert Moeller, eds., Histories of the Aftermath: The Legacies of the Second World War in Europe (New York: Berghahn Books, 2010); Arnd Bauerkämper, ed., Das umstrittene Gedächtnis. Die Erinnerung an Nationalsozialismus, Faschismus und Krieg in Europa seit 1945 (Paderborn: Schöningh, 2012).

${ }^{6}$ Paul Steege, Black Market, Cold War: Everyday Life in Berlin, 1946-1949 (Cambridge: Cambridge University Press, 2007); Richard Bessel, Germany 1945: From War to Peace (New York: Harper Collins, 2009).

${ }^{7}$ Jarausch, After Hitler; Christoph Kleßmann, Die doppelte Staatsgründung. Deutsche Geschichte 1945-1955 (Göttingen: Vandenhoeck \& Ruprecht, 1982); Mary Fulbrook, The Divided Nation: A History of Germany, 1918-1990 (New York: Oxford University Press, 1992), part II.
} 
Iron Curtain. The book is an in-depth study of the intersection between two sister cities, Sonneberg and Neustadt in Upper Franconia, which were home to Germany's largest divided population outside Berlin. It demonstrates that after occupation by American and Soviet troops, respectively, the inhabitants of each city, who had much in common, quickly formed opposing interests and identities and demanded greater border control on both sides-long before East Germany fortified its border with West Germany. Sheffer argues that a wall of the mind shaped the wall on the ground, and East and West Germans became part of, and helped perpetuate, the barriers that divided them. ${ }^{8}$ Other recent research likewise approaches the history of the two Germanys in a more entangled way as demonstrated by the chapters of the 2011 Oxford Handbook of Modern German History, edited by Helmut Walser Smith, among them Andrew I. Port's contribution, "Democracy and Dictatorship in the Cold War: the Two Germanies, 1949-1961."9

Most studies of entangled East and West German history have limited their scope to politics and economics while giving short shrift to social and cultural phenomena and gender history. Even today, the gender perspective is not a self-evident part of post-1945 historical scholarship, unlike class or age, as the 2019 volume Gendering Post-1945 German History: Entanglements, edited by Karen Hagemann, Donna Harsch, and Friederike Brühöfener, demonstrates. Many scholars still ignore the increasing number of studies by historians of women and gender on contemporary German history, which has, with some exceptions, too paid little attention to intersections and interrelationships between the two countries until the late 1990s. ${ }^{10}$

Two of the first comparative and relational monographs that systematically included the perspective of gender were Uta Poiger's 2000 book Jazz, Rock, and Rebels: Cold War Politics and American Culture in a Divided Germany ${ }^{11}$ and Carola Sachse's 2002 study of the history of the monthly day-off for housework granted to working women in both German states, Der Hausarbeitstag: Gerechtigkeit und Gleichberechtigung in Ost und West, 1939-1994. ${ }^{12}$ Both scholars showed how gender, in particular ideas about the family and gender roles, became a central marker of difference between the East and the West in the Cold War era. The model of the dual-earner family with a working wife and mother became iconic for the GDR, and the notion of the male-breadwinner family with a female homemaker and

\footnotetext{
${ }^{8}$ Edith Sheffer, Burned Bridge: How East and West Germans Made the Iron Curtain (New York: Oxford University Press, 2011).

${ }^{9}$ See Andrew I. Port, "Democracy and Dictatorship in the Cold War: The Two Germanies, 1949-1961," in The Oxford Handbook of Modern German History, ed. Helmut Walser Smith (Oxford: Oxford University Press, 2011), 619-43; also Udo Wengst and Hermann Wentker, eds., Das doppelte Deutschland. 40 Jahre Systemkonkurrenz (Berlin: Ch. Links, 2008); Frank Bösch, ed., Geteilte Geschichte. Ost und Westdeutschand 1970-2000 (Göttingen: Vandenhoeck \& Ruprecht, 2015).

${ }^{10}$ See Karen Hagemann, Donna Harsch, and Friederike Brühöfener, eds., Gendering Post-1945 German History: Entanglements (New York: Berghahn Books, 2019), as well as Julia Paulus, Eva-Maria Silies, and Kerstin Wolff, eds., Zeitgeschichte als Geschlechtergeschichte. Neue Perspektiven auf die Bundesrepublik (Frankfurt/Main: Campus, 2012); Karen Hagemann and Sonya Michel, eds., Gender and the Long Postwar: The United States and the Two Germanys, 1945-1989 (Baltimore, MD: John Hopkins University Press, 2014).

${ }^{11}$ Uta Poiger, Jazz, Rock, and Rebels: Cold War Politics and American Culture in a Divided Germany (Berkeley: University of California Press, 2000).

${ }^{12}$ Carola Sachse, Der Hausarbeitstag. Gerechtigkeit und Gleichberechtigung in Ost und West, 1939-1994 (Göttingen: Wallstein, 2002).
} 
part-time earner for the FRG. ${ }^{13}$ This core idea of the Cold War gender order in East and West Germany informed most other areas of their economy, society, and culture, as research by several gender historians shows. ${ }^{14}$

Three decades after the "peaceful revolution" in the GDR and German reunification, a fresh look at the immediate postwar period is necessary in order to understand the decisions and policies that structured the subsequent decades. This special issue therefore presents some recent scholarship by younger American and German historians and cultural studies scholars, who have just finished their dissertations or have recently published their first monograph. The well-known British historian Mary Fulbrook contributed the introductory article on justice, guilt, and consolidation in East and West Germany after Nazism. ${ }^{15}$ The work of all authors in this special issue goes beyond Tony Judt's synthesis of the "Long Postwar"16 in exploring previously neglected topics while employing such methodologies as gender history, cultural studies, and media analysis.

The special issue centers on two main subjects: First, it explores how both states and societies transitioned from war and Nazi dictatorship to peace, focusing on the discourses and politics surrounding the "burdens" of the past. And second, it analyzes some efforts to create new and better "beginnings" that would prevent the recurrence of the nightmares of dictatorship, war, and genocide in the future. Since the Cold War pushed the postwar departures into contrasting directions, the subsequent texts either present fully developed comparisons between East and West Germany or focus at least on analyzing one state's, society's, or culture's entanglement with the other, which was often, as some articles will demonstrate, not equal at all: the GDR tended to look more to the FRG than vice versa. In this introduction, we first discuss some of these "burdens" and "beginnings," and then conclude with suggestions for directions of research that are just beginning to emerge. In this way, the special issue sheds new light on the problematic Nazi legacy, explores the distinctions and parallels between East and West Germany, and sketches some possibilities for future work.

\section{Burdens of the Nazi Past}

To the dazed and relieved survivors in 1945, the legacy of the collapsed Third Reich was so devastating and overpowering that they devoted all their energy to just go on living. In the perception of many contemporaries, after the total defeat the triumphant Volksgemeinschaft

\footnotetext{
${ }^{13}$ See Robert G. Moeller, Protecting Motherhood: Women and the Family in the Politics of Postwar West Germany (Berkeley: University of California Press, 1993); Christine von Oertzen, The Pleasure of a Surplus Income: Part-Time Work, Gender Politics, and Social Change in West Germany, 1955-1969 (New York: Berghahn Books, 2007); Donna Harsch, Revenge of the Domestic: Women, the Family, and Communism in the German Democratic Republic (Princeton, NJ: Princeton University Press, 2007).

${ }^{14}$ For the extensive research on the women's and gender history of the FRG and GDR since the 1990s, see Hagemann et al., Gendering Post-1945 German History. Examples of comparative or entangled monographs are Katrin Schäfgen, Die Verdoppelung der Ungleichheit. Sozialstruktur und Geschlechterverhältnisse in der Bundesrepublik und der DDR (Opladen: VS Verlag für Sozialwissenschaften, 2000); Heike Schröter, Geschichte ohne Frauen? Das Frauenbild in den Schulgeschichtsbüchern der BRD und der DDR von 1949 bis 1989 (Frankfurt/Main: Hänsel-Hohenhausen, 2002); Leonie Treber, Mythos Trümmerfrauen. Von der Trümmerbeseitigung in der Kriegs- und Nachkriegszeit und der Entstehung eines deutschen Erinnerungsortes (Essen: Klartext, 2014).

${ }^{15}$ The article is based on her recent book, Mary Fulbrook, Reckonings: Legacies of Nazi Persecution (New York: Oxford University Press, 2019).

${ }^{16}$ Tony Judt, Postwar: A History of Europe Since 1945 (London: Penguin Books, 2005).
} 
(community of the people) of National Socialism transformed into a battered Schicksalsgemeinschaft (community of fate), sharing a common suffering. With the Reich gone, Prussia dissolved, the large territories east of the Oder and Neisse Rivers lost, the remaining parts of the country occupied and divided into four administrative zones by the Allies, and all political autonomy gone, it is astounding that some sense of national identity and hope for the future in a better Germany survived at all. After the defeat and collapse of the Third Reich, the constant invocation of the nation by Nazi propaganda had so discredited nationalism that further patriotic appeals fell on deaf ears with a population merely struggling to stay alive from day to day due to lack of food and fuel, damaged or destroyed housing and infrastructure, not to mention devastated landscapes. ${ }^{17}$ Although the physical difficulties were enormous, the mental and psychological challenges of dealing with the Nazi legacy were equally momentous.

Many of the crucial decisions were made by the Allied powers, but Germans also participated in shaping their future. The occupation authorities insisted on the three $d$ s of their occupation policy - demilitarization, denazification, and decartelization-which they combined with attempts of reeducation and redemocratization at least in the three western zones. But Germans also debated and pursued alternative models for postwar politics, economy, and society. On the left, hopes were especially high because the members of both newly founded parties in the West, the KPD and the SPD, like the supporters of the SED in the East, perceived the defeat of the Nazis as a "liberation" and imagined for the future a more equal, social, peaceful, and democratic Germany that would have learned the lessons from the "failures" of the Weimar Republic. Christian-conservatives, organized mainly in the West CDU, her Bavarian sister party the Christian Social Union (Christlich-Soziale Union, CSU), and the East CDU, and liberals who in the West formed the Free Democratic Party (Freie Demokratische Partei, FDP) and in the East the Liberal Democratic Party (LiberalDemokratische Partei Deutschlands, LDPD), in contrast, fought early on against any "alternative" socialist visions for the reconstruction of Germany.

Both Allied policies and German attempts to master their own fate were, however, more and more overshadowed by the looming Cold War, which increased the tensions not only between the East and the West, but also inside the four occupation zones and later two German states. In the West, anticommunist and antisocialist sentiments quickly rose, which made it harder for the SPD to develop an alternative policy or take advantage of the credibility offered by its antifascist past and resistance against National Socialism. ${ }^{18}$ Anticommunism led in the newly founded FRG to the persecution of communists and the ban of their party and other communist organizations in $1956 .{ }^{19}$ In the Soviet zone, any "revanchist" attempts by conservatives, liberals, and former social democrats were suppressed as well. Even supporters of a more democratic and open socialist society in the East were persecuted and imprisoned, as were other more conservative opponents of

\footnotetext{
${ }^{17}$ For an overview, see Keith Lowe, Savage Continent: Europe in the Aftermath of World War II (New York: St. Martin's Press, 2012).

${ }^{18}$ See Kristina Meyer, Die SPD und die NS-Vergangenheit, 1945-1990 (Göttingen: Wallstein Verlag, 2015); also Kurt Klotzbach, Der Weg zur Staatspartei. Programmatik, praktische Politik und Organisation der deutschen Sozialdemokratie, 1945-1965 (Bonn: J.H.W. Dietz, 1996 [1982]).

${ }^{19}$ See Patrick Major, The Death of the KPD: Communism and Anti-Communism in West Germany, 1945-1956 (Oxford: Clarendon Press, 1997).
} 
the regime, which struggled to maintain stability. ${ }^{20}$ It is this founding context that needs to be recalled in order to understand the divergent roads taken and the alternatives missed in the attempts to fashion "a better Germany" out of the wreckage of the Third Reich.

A crucial part of coming to terms with Nazi complicity was the refashioning of personal experiences and memories that ranged from denial of guilt to acceptance of individual responsibility. ${ }^{21}$ In her contribution, Mary Fulbrook looks both at legal retribution and popular remembrance, stressing that the intense confrontation with the past in the early postwar period gave way to a more apologetic response in later decades. She contends in the one hand that only a minority of individuals involved in Nazi crimes were prosecuted after the war and that the transnational history of trials is only beginning to be explored. On the other hand she argues that the ways in which those who were tainted by complicity reframed their personal life stories are even less well understood. Millions had been willing facilitators, witting beneficiaries, or passive (and perhaps helpless) witnesses of Nazi persecution; many had been actively involved in sustaining Nazi rule. She claims that perhaps a quarter of a million had personally killed Jewish civilians, and several million had direct knowledge of genocide. She therefore asks: How did these people reenvision their own lives after Nazism? And how did they reinterpret their own former behaviors-their actions and inaction - in light of public confrontations with Nazi crimes and constructions of "perpetrators" in trials? Going beyond well-trodden debates about "overcoming the past," this article, summarizing the main arguments of her 2019 book Reckonings: Legacies of Nazi Persecution the Quest for Justice, which critically explores patterns of personal memory among East and West Germans after Nazism. ${ }^{22}$

One widespread collective memory of postwar Germans was the narrative of "flight and expulsion," analyzed in the next contribution by Peter N. Gengler. ${ }^{23}$ After 1945, an estimated 12.5 million citizens of the collapsed German Reich and members of German minorities from other east-central European regions had to be integrated in four occupations zones and the subsequent two German states. Standard assessments of the postwar integration of some 8 million German expellees in the western occupation zones stress such factors as the "economic miracle" and the 1952 "equalization of burdens" law as crucial milestones. Meanwhile, studies on the integration of a further 4 million expellees, known as "new

\footnotetext{
${ }^{20}$ As a recent local studies on the regime, see Andrew I. Port, Conflict and Stability in the German Democratic Republic (Cambridge: Cambridge University Press, 2007); Christian Halbrock, "Freiheit heißt, die Angst verlieren." Verweigerung, Widerstand und Opposition in der DDR-Der Ostseebezirk Rostock (Göttingen: Vandenhoeck \& Ruprecht, 2014); on the social and cultural strategies with which the GDR tried to integrate its citizens, see Mary Fulbrook and Andrew I. Port, eds., Becoming East Germans: Socialist Structures and Sensibilities after Hitler (New York: Berghahn Books, 2013).

${ }^{21}$ Recently, Konrad H. Jarausch, Broken Lives: How Ordinary Germans Experienced the 20th Century (Princeton, NJ: Princeton University Press, 2018), 237-78; see also Frederic C. Tubach, German Voices: Memories of Life during Hitler's Third Reich (Berkeley: University of California Press, 2011); Katharina von Kellenbach, The Mark of Cain: Guilt and Denial in the Post-War Lives of Nazi Perpetrators (New York: Oxford University Press, 2013).

${ }^{22}$ See Fulbrook, Reckonings, as well as Mary Fulbrook, Dissonant Lives: Generations and Violence Through the German Dictatorships (Oxford: Oxford University Press, 2011), and Mary Fulbrook, Small Town Near Auschwitz: Ordinary Nazis and the Holocaust (Oxford: Oxford University Press, 2012).

${ }^{23}$ This article is based on Peter N. Gengler's dissertation, "Constructing and Leveraging 'Flight and Expulsion': Expellee Memory Politics and Victimhood Narratives in the Federal Republic of German, 1944-1990" (PhD diss., University of North Carolina at Chapel Hill, 2019).
} 
settlers," in the Soviet zone emphasize the rapid granting of equality and their engagement in the labor market.

Gengler argues that a close examination from a cultural-historical perspective of how "flight and expulsion" were discussed in the East and the West by the expellees themselves, the media, and politicians provides fresh insights into not only the evolution of the collective memory of the largest forced migration in European history, but also the competing approaches of the integration of the expellees and refugees. Initially wartime fates and lost homelands were prominent subjects in public discourse in both states, but in the context of the rising Cold War eventually such debates were strictly prohibited in the GDR while they added to the victimization narrative of the FRG. In the East, the SED condemned National Socialism as the cause of this misfortune. Its integration policy more directly addressed refugee and expellees' needs, labeled as "resettlers," using them as arguments for socialization in agriculture. In the West, the expellees themselves made a concerted effort to educate domestic and international audiences through the use of "sympathy narratives" while clamoring for material help and psychological recognition. Their fate was used by conservatives in a revanchist rhetoric demanding a "reunification" in "the old boarders of Germany." 24

Another aftermath of Nazi dictatorship and its defeat was the maelstrom of so-called displaced persons (DPs) swirling around in central Europe. They were cared for by the United Nations Relief and Rehabilitation Administration (UNRRA), founded in November 1943. At the end of World War II, at least 11 million people had been displaced from their home countries, about 7 million of them in occupied Germany. They were prisoners of war, forced laborers, inmates of concentrations camps, and refugees. Some of these DPs wanted to be repatriated, others insisted on emigrating because their homes had been destroyed and their places of origin now belonged to a different European state. Between 1945 and 1947 the number of DPs dramatically decreased. Those who were easily classified and were willing to be repatriated were rapidly sent back to their country of origin. But for others the situation was more difficult. In 1947, some 850,000 people still lived in DP camps across Europe. ${ }^{25}$

\footnotetext{
${ }^{24}$ For recent studies, see Pertti Ahonen, After the Expulsion: West Germany and Eastern Europe, 1945-1990 (Oxford: Oxford University Press, 2003); Andreas Kossert, Kalte Heimat. Die Geschichte der deutschen Vertriebenen nach 1945 (Munich: Siedler Verlag, 2008); Eva Hahnová and Hans-Henning Hahn, Die Vertreibung im Deutschen Erinnern. Legenden, Mythos, Geschichte (Paderborn: Schöningh, 2010); Maren Röger, Flucht, Vertreibung und Umsiedlung. Mediale Erinnerungen und Debatten in Deutschland und Polen seit 1989 (Marburg: Verlag Herder-Institut, 2011); Mathias Beer, Flucht und Vertreibung der Deutschen. Voraussetzungen, Verlauf, Folgen (Munich: Beck, 2011); Raymond M. Douglas, Orderly and Humane: The Expulsion of the Germans After the Second World War (New Haven, CT: Yale University Press, 2012); on gender images in the discourse, Kirsten Möller, Geschlechterbilder im Vertreibungsdiskurs. Auseinandersetzungen in Literatur, Film und Theater nach 1945 in Deutschland und Polen (Frankfurt/Main: Peter Lang, 2016); in a comparative perspective, Philipp Ther, The Dark Side of Nation States: Ethnic Cleansing in Modern Europe (New York: Berghahn Books, 2014).

${ }^{25}$ For the background, see Anna Marta Holian, Between National Socialism and Soviet Communism: Displaced Persons in Postwar Germany (Ann Arbor: University of Michigan Press, 2011); Jessica Reinisch and Elizabeth White, eds., The Disentanglement of Populations: Migration, Expulsion and Displacement in Post-War Europe, 1944-9 (Basingstoke: Palgrave Macmillan, 2011); Corine Defrance et al., Personnes déplacées et guerre froide en Allemagne occupée = Displaced Persons and the Cold War in Occupied Germany = Displaced Persons und Kalter Krieg im besetzten Deutschland (Bruxelles: Peter Lang, 2015).
} 
Many more people than these officially recognized DPs, however, were displaced during and after the war, millions of them Germans. The latter were not cared for by UNRRA, but were thrust upon the local German authorities. Derek Holmgren's contribution looks at the example of one important camp for dislocated Germans: the central transit camp in Friedland in Lower Saxony, which lay in the British occupation zone bordering both the American and Soviet zones. ${ }^{26}$ Established in September 1945, Friedland became the linchpin in a system designed to collect, register, aid, and resettle displaced Germans. The camp processed several million people and provided them with papers so they could obtain ration cards, housing permits, and help with jobs. Its population included German evacuees, expellees, soldiers released from prisoner of war camps, and homeless young people, mainly men, without family. Holmgren's analysis of the interplay between imperatives for control (registration, categorization, and transit restrictions), amelioration (aid distribution and medical services), and reintegration (assignment to institutions and placement into jobs) shows that this regulatory form of humanitarianism served both the state and the displaced individuals. His analysis of the humanitarian approach of state-run transition camps like Friedland focuses on two groups of camp inmates: returning German POWs and unsupported male adolescent refugees traveling between the different occupation zones and later the two German states. The study shows how displaced Germans, who did not qualify as DPs, were administered and treated and helps to deconstruct the Cold War myth of Friedland being a "Gateway to Freedom": refugees were transferred in both directions, east and west, across the GermanGerman border.

Another troubling aspect of the Nazi legacy was the disposition of the small number of Jewish survivors of the concentration camps. At the end of 1946, the number of Jewish DPs was estimated at 250,000, of whom 185,000 lived in camps in Germany, 45,000 in Austria, and 20,000 in Italy. Most of these Jewish DPs were refugees from Poland, many of whom had fled the Germans into the interior of the Soviet Union during the war. Other Jewish DPs came from Czechoslovakia, Hungary, and Romania. All hoped to find a new homeland. Only approximately 15,000 German Jews returned after 1945 to one of the four Allied occupation zones; ironically, for that reason they also did not receive DP status. $^{27}$

Andrea A. Sinn examines their situation in her contribution by focusing on the reconstitution of a German-speaking Jewish community in the four post-1945 occupation zones and later two German states. ${ }^{28}$ She discusses the various forms of isolation and stigmatization Jewish communities experienced in the postwar period and the ways in which these communities contributed to the process of democratization and rehabilitation of East and West Germany. Aiming for a better understanding of the position that Jews took up within the German as well as the Jewish environment after the Second World War, her article stresses

\footnotetext{
${ }^{26}$ The article is based on Derek Holmgren's dissertation, “'Gateway to Freedom': The Friedland Refugee Transit Camp as Regulating Humanitarianism, 1945-1960” (PhD diss., University of North Carolina at Chapel Hill, 2015).

${ }^{27}$ See Angelika Königseder and Juliane Wetzel, eds., Waiting for Hope: Jewish Displaced Persons in Post-World War II Germany (Evanston, IL: Northwestern University Press, 2001); Michael Berkowitz and Avinoam J. Patt, eds., We Are Here: New Approaches to Jewish Displaced Persons in Postwar Germany (Detroit, MI: Wayne State University Press, 2010).

${ }^{28}$ See Andrea A. Sinn, Jüdische Politik und Presse in der frühen Bundesrepublik (Göttingen: Vandenhoeck \& Ruprecht, 2014).
} 
the institutional dimension of Jewish return by focusing on the question of rebuilding Jewish life in East and West Germany. ${ }^{29}$ Though there were ugly public traces of antisemitism in the Federal Republic, eventually conflicting German, Jewish, and international conceptions of Jewish life during the early postwar years succeeded in restoring a space for a limited renaissance of the Jewish community. In contrast, the class-based antifascism of the GDR, which initially looked more welcoming, ultimately led to the atrophy of an ever smaller Jewish community in the East, an asymmetry that still has not yet been overcome.

Taken together, these articles shed new light on the practical issues of postwar survival as well as on the mental questions of confronting memories of mass death and mass murder. By stressing the active engagement with the recent past, Mary Fulbrook's article revises the prevalent picture of post-1945 denial and questions the self-congratulatory tone of later critical decades. By stressing the construction of a common narrative of "flight and expulsion" out of many disparate stories, Peter N. Gengler shifts attention to claims of German suffering that dominated the private memories of the Second World War in the first postwar decade and the importance of their recognition for the integration of ethnic German refugees from eastern Europe in both Germanys. In detailing the desperate attempts to cope with the influx of millions of German displaced people, Derek Holmgren opens up new dimensions of "regulated state humanitarianism" as a basis for their difficult but ultimately successful process of integration. And finally, by analyzing the evolution of a German-speaking Jewish community represented by the Central Council of Jews in Germany (Zentralrat der Juden in Deutschland) as an organization of Jews in both Germanys until 1961, Andrea A. Sinn explores the conflicting pressures on that minority of Jews that was willing to remain in the country of the perpetrators in spite of lingering antisemitism and international Jewish criticism. ${ }^{30}$ Each article in its own way therefore challenges some aspects of the current picture by adding nuance and new perspectives in order to better illuminate the difficult and ambiguous process of dealing with the burdens of the Nazi past and World War II.

\section{New Postwar Beginnings}

Although 1945 was far from a Stunde Null (zero hour), a term used by many German contemporaries to describe the situation in the first postwar years, the defeat of the Nazi dictatorship provided chances for a new personal and political beginning. Most people were relieved just to be alive and had their hands full in coping with the manifold challenges of providing food, shelter, work, and so on. ${ }^{31}$ Especially shocked when the vaunted Third Reich crumbled, the generation of the Hitler Youth and the League of German Girls began to slowly realize that it had been betrayed by the Führer and that National Socialism was responsible for the disaster. Many autobiographies show that the intellectuals were also busy sifting through traditions in order to see what parts of the past had not been damaged beyond repair. Suddenly, churches filled with previously absent parishioners in search of spiritual sustenance while secular individuals frequented cultural centers including theaters to find elements of humanism that might give their future lives a new meaning.

\footnotetext{
${ }^{29}$ See Atina Grossmann, Jews, Germans, and Allies: Close Encounters in Occupied Germany (Princeton, NJ: Princeton University Press, 2009).

${ }^{30}$ Norbert Frei, Adenauer's Germany and the Nazi Past: The Politics of Amnesty and Integration (New York: Columbia University Press, 2002).

${ }^{31}$ Jarausch, Broken Lives, 237-78.
} 
After the dissolution of the government under Admiral Karl Dönitz on May 23, 1945, and the disbanding of the Wehrmacht, the only remaining political institutions were local mayors, city councils, and nonpartisan action committees that were busy dealing with emergency measures. In the reemerging competition of the quickly founded political parties, the communists and social democrats at first had an advantage because they had been the most resolute antifascists. In the first postwar months, many leftists, especially in the younger generation, had hoped that the two reestablished parties, the KPD and the SPD, would overcome their division, which had dramatically weakened the antifascist struggle against the Nazis before 1933. The creation of the communist-dominated SED by a forced unification of the KPD and SPD in the Soviet zone, however, quickly dashed such hopes in workingclass and intellectual circles in both zones. In addition, the emerging Cold War complicated the situation for the left, not only in the West. It contributed to a polarization of the political culture in all occupation zones, fostered the rise of conservatism in the West, and hardened communist control in the East. ${ }^{32}$

The Cold War confrontations between the East and the three West German zones and their two successor states affected all areas of the economy, politics, society, and culture, including foreign policy. The GDR and FRG became locked in a fierce competition to appear as "the better Germany" in the international community, which was especially important for East Germany. Its international acceptance as a sovereign state was the focus of its foreign policy for its first twenty-five years of existence because it was the precondition for the conclusion of binding international contracts. This attempt was made difficult by the West German Hallstein Doctrine, proclaimed in 1955 by the FR G government, which prohibited normal relations between the FRG and any country that recognized the GDR. Attitudes toward the GDR only changed with the FRG's new Ostpolitik, pursued by the first social democratic chancellor, Willy Brandt. Between 1969 and 1974, his SPD/FDP government not only redefined West Germany's relation with its Nazi past, but also altered the global environment of the Cold War and the German-German relationships. The new Ostpolitik broke the Cold War stalemate in Germany and Europe, leading to a détente and better relations between the FRG and GDR, represented by the Treaty Concerning the Basis of Relations between the Federal Republic of Germany and the German Democratic Republic (Grundlagenvertrag) signed in December 1972. ${ }^{33}$

In his contribution, Lorn E. Hillaker investigates the competition in cultural diplomacy of the GDR and the FRG in the 1950s, which aimed to win the support of foreign states. He focuses on the illustrated magazines GDR Review and Scala, produced on behalf of the foreign ministries of the GDR and FRG, in order to explore how each government tried to convince not only its own allies within its respective Cold War blocs but also other states that its part of the country was the "better Germany" that had repented for its misdeeds and would promise a better future. ${ }^{34}$ Although East Germany initially took the lead in appealing for recognition to its neighbors and the Third World, West Germany countered beginning in the mid-1950s.

\footnotetext{
${ }^{32}$ Jarausch, Broken Lives; and Dirk Moses, German Intellectuals and the Nazi Past (Cambridge: Cambridge University Press, 2007).

${ }^{33}$ See Carole Fink, Ostpolitik, 1969-1974: European and Global Responses (New York: Cambridge University Press, 2009.)

${ }^{34}$ This article is based on Lorn E. Hillaker's dissertation, "Promising a Better Germany: Competing Cultural Diplomacies Between West and Easy Germany, 1949-1989” (PhD diss, University of North Carolina at Chapel Hill, 2019).
} 
Hillaker argues that cultural diplomacy offered a route outside of traditional channels for a policy that attempted to cultivate other states' and peoples' favorable views of either Germany. Thematically, much of the cultural diplomatic media from this early period countered the immediate legacy of the Third Reich and the Second World War among audiences who had only recently been enemies by describing the rebuilding of each state and its adherence to international treaties. As division progressed in the later 1950s, the GDR and the FRG began to focus more on cultivating an image of a peaceful, friendly state and society superior to both the Nazi past and the other contemporary Germany, ultimately setting the terms for the image-building contest to continue throughout the Cold War. Gender images played, according to Hillaker, a remarkably important role in the self-presentation of both states and societies in the illustrated magazines GDR Review and Scala. Images of women were used as special evidence of each respective state's "superiority" and "progressiveness." 35

One test case for the economic and social performance of each German regime was its financial and emotional treatment of elderly citizens in need of government support. James G. Chappel explores the imagination and administration of aging in 1950s East Germany in his contribution, showing how and why it differed from West Germany. ${ }^{36}$ Drawing on his research on People's Solidarity (Volkssolidarität), the premier eldercare organization in the GDR, he revisits Konrad H. Jarausch's depiction of East Germany as a "welfare dictatorship." Although the concept might apply to some elements of SED rule, especially in the Honecker era, he argues, it obscures key aspects of the SED's experiments with the care for elderly in the 1950s. GDR policymakers and activists sought a form of eldercare different from the paternalistic West German model that continued Bismarck's Sozialpolitik (social policy) of a pension system. Instead, the GDR model drew on the alternative Weimar tradition of the communist welfare organization Red Help (Rote Hilfe), as inflected through the realities of the 1950s. The SED built on socialist self-help and female activism alongside feminist attempts to reimagine the family unit. It was no accident that one of the premier theorists of socialist aging was the son of Clara Zetkin, the leader of the communist women's organization before $1933 .{ }^{37}$

In welfare, including eldercare, gender played an important role for several reasons. One was that the majority of the elderly population in the GDR were women. The Soviet zone had a massive demographic surplus of women, who accounted for 57.5 percent of the population; this surplus increased further during the 1950s. Until the construction of the Berlin Wall in 1961, the flight to West Germany, especially of young and qualified men, led to an aging and female population of the GDR and a worsening labor shortage. Thus, women of all ages were needed in the workforce. Another aspect of gender's importance for Chappel's study was the tradition of the gendered nature of welfare policy and practice. Already in the Weimar Republic welfare was also for the left the task of the women. In parliamentary

\footnotetext{
${ }^{35}$ Frank Trommler, Kulturmacht ohne Kompass: Deutsche auswärtige Kulturbeziehungen im 20. Jahrhundert (Cologne: Böhlau Verlag, 2014).

${ }^{36}$ The article is based on James G. Chappel's research for his new book project, "Old Volk: The Invention of Old Age in Modern Germany."

${ }^{37}$ Konrad H. Jarausch, ed., Dictatorship as Experience: Towards a Socio-Cultural History of the GDR (New York: Berghahn Books, 1999); Hans-Günter Hockerts, Sozialpolitische Entscheidungen im Nachkriegsdeutschland. Alliierte und deutsche Sozialversicherungspolitik 1945 bis 1957 (Stuttgart: Klett-Cotta, 1980).
} 
politics as well as the newly founded welfare organizations of the labor parties, the communist Red Help and the social democratic Workers' Welfare (Arbeiterwohlfahrt), women dealt with social issues because they were assumed to be better suited for it, based on their "maternal nature." Despite their newly achieved political equality in 1919, women continued to be perceived as "equal but different." The gendered division of labor in the economy, society, and the family was extended to politics, where women became responsible for everything defined as "female," including education, family, health, and welfare. ${ }^{38}$

Such a gendered politics resumed in both postwar Germanys. The Weimar Republic had opened spaces for women in political activism and influence, but at the same time reinforced the gendered division of labor and kept women away from all male-coded areas of politics. This situation changed in the FRG only with the rise of the new women's movement in the late 1960s, which challenged the traditional gendered division of labor and argued that women were not born but made by society and culture. After 1945, however, the notion "equal but different" stood for the contemporaries not yet in opposition to the equality of women as a legal principle and an actual practice that both German constitutions of 1949 demanded. But the interpretation of this principle in legal practice was contested. The reform of family and marriage law became one such battleground. Women on the left in both German states demanded complete equality in civil law and argued that this reform would finally recognize the important contributions that women had made in fighting on the homefront and keeping their families alive during both world wars and in the immediate postwar years.

Alexandria N. Ruble analyzes in her contribution the lengthy process of this female struggle for equal civil rights in the FRG and GDR and its entanglements. ${ }^{39}$ After 1945, Germans on both sides of the Iron Curtain inherited a civil code that dated back to the Bürgerliche Gesetzbuch (BGB) of 1900, which designated women as second-class citizens in marital property, spousal rights, and parental authority. Liberal and socialist women in the German Empire and the Weimar Republic already had fought against the BGB. East and West German female politicians and women activists continued this struggle after 1945 and pursued parallel reforms of the longstanding law as part of the larger postwar reconstruction projects. Ruble compares how East and West German legislators envisioned the roles of women, gender, and the family in their new, postfascist German states. She not only demonstrates that in both countries, Nazism's treatment of women and the family served as a negative reference point for legislators, but she also emphasizes, like Chappel, the continuities to Weimar Germany. As the Cold War intensified, East and West German politicians often went one step further in casting the other Germany's policies on gender and the family as

\footnotetext{
${ }^{38}$ See Christiane Eifert, Frauenpolitik und Wohlfahrtspflege. Zur Geschichte der sozialdemokratischen Arbeiterwohlfahrt (Frankfurt/Main: Campus, 1993); Karen Hagemann, Frauenalltag und Männerpolitik. Alltagsleben und Gesellschaftliches Handeln von Arbeiterfrauen in der Weimarer Republik (Bonn: J.H.W. Dietz, 1990); Silvia Kontos, Die Partei Kämpft wie ein Mann: Frauenpolitik Der KPD in Der Weimarer Republik (Basel: Stroemfeld-Verlag: 1979).

${ }^{39}$ The article is based on Alexandria N. Ruble's dissertation, “'Equal but not the Same': The Struggle for 'Gleichberechtigung' and the Reform of Marriage and Family Law in East and West Germany, 1945-1968" (PhD diss., University of North Carolina at Chapel Hill, 2017).
} 
a central marker of difference from their own system in an attempt to distance themselves from both the Nazi past and the other Germany. ${ }^{40}$

The ideological competition between the two Germanys extended into the spheres of culture and mass media such as radio, television, and cinema, but here too comparative and entangled studies are still rare. ${ }^{41}$ Priscilla D. Layne's contribution concentrates on the highly gendered representation of rebellious working-class youths in East and West German movies of the $1950 \mathrm{~s} .{ }^{42}$ By contrasting these teenage movies, her article provides an intriguing approach to a comparative and entangled cultural history informed by film studies. In the 1950s, several American rock 'n' roll films took West Germany by storm. Though these movies addressed the problem of delinquent American youth, their themes and music resonated with German audiences. Even if these films were not screened in the East, the open border between East and West, especially in Berlin, allowed both populations of young people to see these films and as a result adopt American clothing style and music. In 1956 and 1957, respectively, the West German film Die Halbstarken (Teenage Wolfpack) and the East German film Berlin-Ecke Schönhauser (Berlin-Schönhauser Corner) addressed the "youth problem" in its specific context. Layne specifically compares the portrayal of femininity in these two films. Although both movies attribute the problem of delinquent youth to consumerism, pop culture, and "weak parents," they take strikingly different approaches to young women. While the West German film clearly gendered and linked consumerism to a dangerous and erotic femininity that brings down young men, the East German film presented consumerism as a seductive offer of Western capitalism that destroys young people and portrayed young women as equals of working-class men. Male and female teenagers would enjoy a prosperous future if they chose the socialist path. ${ }^{43}$

All four articles suggest that the search for a new, post-Nazi beginning took place in a triangle of repudiating the tainted past and opposing the ideological alternative of the present. Neither Germany wanted to appear as having anything to do with the Third Reich, although the Federal Republic's policy was more inclusive of penitent former Nazis, whereas the GDR officially insisted on strict demarcation. At the same time, the Christian-conservative West German government under the leadership of the CDU, in power from 1949 to 1966, and the East German government, controlled by the SED, made considerable efforts to reject the renewal of the rival on the other side of the Iron Curtain. Lorn E. Hillaker's article shows

\footnotetext{
${ }^{40}$ For a comparative European perspective, see also Karen Hagemann, Konrad H. Jarausch, and Cristina Allemann-Ghionda, eds., Children, Families, and States: Time Policies of Childcare, Preschool, and Primary Education in Europe (New York: Berghahn Books, 2011).

${ }^{41}$ Exceptions include Poiger, Jazz, Rock, and Rebels; Hans Joachim Meurer, Cinema and National Identity in a Divided Germany, 1979-1989: The Split Screen (Lewiston, NY: Edwin Mellen Press, 2000). For the FRG, see, for example, Heide Fehrenbach, Cinema in Democratizing Germany: Reconstructing National Identity after Hitler (Chapel Hill: University of North Carolina Press, 1995); Hanna Schissler, ed., The Miracle Years: $A$ Cultural History of West Germany, 1949-1968 (Princeton, NJ: Princeton University Press, 2001); Robert G. Moeller, War Stories: The Search for a Usable Past in the Federal Republic of Germany (Berkeley: University of California Press, 2003); for the GDR, Jarausch, Dictatorship as Experience; Katherine Pence and Paul Betts, eds., Socialist Modern: East German Everyday Culture and Politics (Ann Arbor: University of Michigan Press, 2008); Paul Betts, Within Walls: Private Life in the German Democratic Republic (New York: Oxford University Press, 2010).

${ }^{42}$ See also Priscilla D. Layne's recent book, White Rebels in Black: German Appropriation of Black Popular Culture (Ann Arbor: University of Michigan Press, 2018).

${ }^{43}$ Melissa Etzler and Priscilla Layne, eds., Rebellion and Revolution: Defiance in German Language, History and Art (Newcastle: Cambridge Scholars Publishing, 2010).
} 
that the GDR's struggle for recognition as an independent state used a claim to antifascist superiority, while the FRG was content to point to its prosperity and political freedom. In social policy, James G. Chappel demonstrates that East Germany had fewer resources, and therefore developed an activating model of eldercare, while West Germany relied on higher pensions. Similarly, in gender relations Alexandria N. Ruble suggests that the GDR emphasized greater workplace equality of men and women and propagated the dual-earner family model, not the least because it needed the female work force, while the FRG clung to a modified male-breadwinner/female-homemaker family that allowed mothers part-time work combined with a consumption-oriented femininity. Finally, Priscilla D. Layne demonstrates that in dealing with rebellious working-class youth, East German producers constructed a socialist happy end for the main female character in their film, while the West German movie sought to deter such behavior by portraying the dangers of rampant female teenage sexuality. In short, these articles show a higher degree of postwar entanglement than is often assumed, which only more focused and specific case studies like those presented can reveal. ${ }^{44}$ In doing so, all four authors illustrate the need to include gender as an important category of an entangled analysis of postwar German history far beyond gender relations because gendered thinking informed all areas of the economy, society, politics, and culture.

\section{“Deprovincializing” Post-1945 German History}

The articles in this special issue offer not only a fresh perspective on the entanglement of West and East Germany in the immediate postwar period, but they also emphasize the importance of culture and gender. Several of them emphasize, furthermore, the complicated triangle that defined the identity of the two postwar German states and societies: the past, represented by both the democratic tradition of the Weimar Republic and the rejected Nazi regime, and the present, characterized by the existence of two competing states and societies representing the communist authoritarian systems of the Eastern Bloc and the capitalist democratic states and societies of the West.

Despite an increasing number of innovative comparative and entangled studies on post1945 German history, much remains to be done. Most important seems to be its "deprovincialization" by a transnational widening of horizons to compare central European developments to similar tendencies elsewhere. For instance, all European World War II belligerents faced similar challenges of rebuilding their physical environment from massive damage to repair their infrastructure and make their cities livable. They all had to convert their economies from war production to peacetime manufacturing to provide the population with sustenance and fulfill long pent-up wishes for consumer goods. At the same time, all postwar nations had to deal with the psychological damage caused by the war experiences at the homefront and battlefront; everywhere the family seems to have been the most important institution for the integration of returning soldiers. Moreover, virtually all liberated European countries sought to punish perpetrators of war crimes and hunt down former collaborators in order to make them pay for their treason. In politics, they began to review their institutions and debate which reforms had to be undertaken to prevent a recurrence of the

\footnotetext{
${ }^{44}$ Konrad H. Jarausch, “'Die Teile als Ganzes erkennen.' Zur Integration der beiden deutschen Nachkriegsgeschichten," Zeithistorische Forschungen 1, no. 1 (2004): 10-30.
} 
wartime horrors. ${ }^{45}$ Only when German postwar developments are seen as part of a wider transition process from war to peacetime in Europe and beyond will it be possible to distinguish what is peculiar to them.

A more focused international comparison could look at the transformation of the other Axis countries, which faced a similar postfascist transformation after their defeat in 1945. To be sure, their postwar pathways were somewhat different. Austria was allowed to steal away as the "first victim of fascism," while Italy invoked its change of sides in 1943, labeled the Republic of Salò as a puppet regime of the Nazis, and embraced the resistance (resistenza) myth. At the same time, Japan had to confront the shock of nuclear bombardment by a power that claimed to defend human rights. The smaller German allies in eastern Europe were reconstructed on the Soviet model. All of them faced prolonged allied occupation, which demilitarized the countries to make sure that there would not be a World War III. Moreover, they were all "defascistized" in order to destroy the nationalist and racist ideology that had precipitated the war and caused so much suffering among the conquered populations. Under the proconsul tutelage of the victors, all of them underwent a process of cultural reorientation that implanted democratic institutions and gradually brought them back as chastened members of the international community. Comparative research on the actual process of this postfascist transformation in attitudes and behaviors has barely begun due to linguistic and cultural difficulties. ${ }^{46}$

Another perspective on transnational entanglement would be the integration of each part of Germany into its respective Cold War bloc, resulting in Westernization and Sovietization. Though the adoption of American lifestyles and political outlooks in West Germany was more voluntary than the imposition of a Stalinist dictatorship in the East, the processes still exhibited similarities. Both proceeded from a mixture of occupation pressure to follow the example of the victorious power and voluntary adaptation to a system that had proved superior during the war. In both cases, a minority of willing collaborators embraced the system of their occupation power in order to restore some degree of self-determination in the absence of a national government that had been taken over by the Allied Control Council. In each instance the transfer took place through a mixture of official guidelines and private contacts that suggested a different way of being. Of course, the comparison should not be overdone because it made a world of difference whether a lifestyle was freely embraced or dictated by a monopoly party like the SED. The Westernization of the FRG was a majority effort to emulate an attractive example of freedom and prosperity, whereas the Sovietization of the East was a minority project to build the dictatorship of the proletariat. ${ }^{47}$ To offer a more nuanced picture, both processes need to be linked to each other.

Yet another approach to a broader contextualization of postwar history would be to focus on a crucial issue, such as the massive population movements in the wake of Nazi defeat. Though they were causally related to the ethnic cleansing and mass murder of Hitler's quest for living space, most of the literature treats them as separate processes. Monographs

\footnotetext{
${ }^{45}$ William I. Hitchcock, The Bitter Road to Freedom: A New History of the Liberation of Europe (Glencoe: Free Press, 2008); Istvan Deak, Europe on Trial: The Story of Collaboration, Resistance, and Retribution during World War II (Boulder, CO: Westview Press, 2015).

${ }^{46}$ Sebastian Conrad, The Quest for the Lost Nation: Writing History in Germany and Japan in the American Century (Berkeley: University of California Press, 2010).

${ }^{47}$ Konrad H. Jarausch and Hannes Siegrist, eds., Amerikanisierung und Sowjetisierung in Deutschland, 1945-1970 (Frankfurt/Main: Campus, 1997).
} 
on displaced persons largely focus on the fate of Jewish survivors and the question of repatriation of Slavic slave laborers or their emigration to the United States, Canada, or Australia. These studies also look at the laudable efforts of UNRRA to help the surviving victims of Nazi aggression, but tend to slight the fate of the collaborators from the East. In contrast, the German scholarship on flight and expulsion deals with the partly voluntary and largely compulsory eviction of 12 million German speakers from eastern Europe, focusing on actions of the German authorities without paying enough attention to the causes of their displacement. At the same time, Polish studies on the westward shift of millions from their eastern territories into formerly German lands also tend to remain within a national framework, even if both processes are related in the emptying out and repopulation of the same territories. Instead of searching for culprits, it would be more constructive to treat all these processes and various groups as historically related to one another. ${ }^{48}$

Three-fourths of a century after the end of the Second World War ought also to be the time at which to end the competition for suffering and victimhood. Even though in the immediate postwar period, historians still praised national heroes like Winston Churchill or Charles de Gaulle, the rise of Holocaust sensibility has eroded such admiration because the sympathy regime has understandably shifted the emphasis to the victims. Because they were the only group targeted for complete annihilation, European Jews have become the quintessential victims of the Holocaust, eliding their active resistance. Reinforcing their national "martyrology," millions of Poles also have ample reason to consider themselves victimized, thereby denying their partial collaboration in the mass murder. Although they suffered less than any other eastern Europeans, Czechs cling to their victimhood in order to justify the brutal expulsion of the Sudeten Germans. In recent decades, many Germans have begun to resent their role as contrite perpetrators, privately also emphasizing suffering at the fighting front, during the bombardments at home or in flight from the Red Army. In contrast to the actual Nazi victims, this popular feeling raises the moral question of whether perpetrators can also become, in Helmut Kohl's inscription at the Neue Wache, the "Central Memorial of the Federal Republic of Germany for the Victims of War and Dictatorship," victims of "war and aggression." 49

A final area of fruitful comparison would be the different tropes of memory that dominate national recollections of World War II and the Holocaust. A quick survey shows that the West European memories understandably focus on Nazi aggression, national resistance, and eventual liberation. In contrast, many of the east-central European memory cultures are preoccupied with Soviet repression under Stalinist communism, such as the Holodomor of mass starvation in the Ukraine. In Russia, national pride revolves around the victory in the Great Patriotic War, ignoring the domestic repression and domination over client states afterward. Located between the collective memories of their neighbors, the Germans were forced to officially embrace an antifascist public memory, showing contrition in order to be readmitted into the international community. It took France decades to accept a self-critical memory in coming to terms with Vichy collaboration or its long history

\footnotetext{
${ }^{48}$ Gerald Daniel Cohen, In War's Wake: Europe's Displaced Persons in the Postwar Order (New York: Oxford University Press, 2012); Gregor Thum, Uprooted: How Breslau Became Wrocław During the Century of Expulsions (Princeton, NJ: Princeton University Press, 2011).

${ }^{49}$ Charles S. Maier, The Unmasterable Past: History, Holocaust, and German National Identity (Cambridge, MA: Harvard University Press, 1988); Martin Sabrow, ed., Der Streit um die Erinnerung (Leipzig: Helmstedter Colloquien 10, 2008).
} 
of colonialism, which only ended in 1961 with the liberation of Algeria. In Italy only the collapse of the so-called First Republic in 1992 enabled a younger generation of Italian scholars to challenge the postwar myth of the "good Italian." More recently, some East European states such as Hungary and Poland have fallen back into a nationalist interpretation of the past that exculpates their own misdeeds. Although the Stockholm Declaration of the United Nations Conference of the International Holocaust Remembrance Alliance in 2000 established the Holocaust as a common foundation, it is far from certain that this commemoration has become the standard of a European memory culture. Such a comparison shows a fragmented memory landscape in which German self-criticism may be the exception rather than the rule. ${ }^{50}$

\section{Conclusion: Postwar Paradoxes}

The articles of this special issue show that the end of the Second World War and the beginning of the postwar period was a liminal time and space, full of surprising contradictions. The surviving Germans experienced a welter of feelings, ranging from grief and sorrow to relief and exhilaration. For many German nationalists and soldiers, the capitulation was first of all a defeat, the end of dreams of European hegemony and racial purification. For the majority of civilians, surrender meant a cessation of the fighting on the ground and of the ever more lethal bombing from the air. And for the minority of still-living ethnic and political victims, the allied victory signaled liberation from Nazi persecution and incarceration. More than twelve years of National Socialist dictatorship and almost six years of war were finally over, leaving many contemporaries disoriented as to what to do with their recovered lives. With Nazi structures dissolving and government taken over by the victors, individuals above all sought to cope with the chaos of destroyed cities, damaged infrastructure, and lack of food and supplies. And yet, May 1945 also signaled a host of new possibilities of reinventing lives in peace and freedom. ${ }^{51}$ It took four decades for a West German president, the Christian Democrat Richard von Weizsäcker, to explore these multiple meanings of the so-called zero hour in a compelling speech in May 1985.

New research demonstrates that the Nazi burden was much more pervasive than optimistic accounts of almost instant democratization after 1945 are willing to admit. The physical removal of Nazi symbols and even the rebuilding of infrastructure, factories, and housing were more quickly completed than expected. Cleansing personnel, however, took longer because with more than 7 million Nazi Party members and more in various auxiliaries, a considerable part of the population was implicated that could not be sidelined forever. The denazification procedure was a highly imperfect mechanism to identify some of the key culprits and to allow the rest of the followers to renounce their errors and convert to democracy. The study of various West German ministries shows that postwar institutions were therefore filled with former Nazis, only some of whom had learned from the catastrophic results of the politics of the Third Reich that the Nazi ideology was despicable. More subtle and demanding yet was the purging of language from racist prejudices by substituting inoffensive terminology. Redefining terms and reframing discourses was not enough; the thinking and mentality

\footnotetext{
${ }^{50}$ Klaus Leggewie, Der Kampf um die europäische Erinnerung: Ein Schlachtfeld wird besichtigt (Munich: Beck, 2011); Konrad H. Jarausch and Thomas Lindenberger, eds., Conflicted Memories: Europeanizing Contemporary Histories (New York: Berghahn Books, 2011).

${ }^{51}$ See Jarausch, Broken Lives.
} 
of people had to change too. Both are much more difficult for historians to study. The research challenge is therefore not just to discover dubious involvement in the Nazi past by contemporaries, such as Walter Jens or Günter Grass, but also the more delicate tracing of the gradual fading of Nazi outlooks and expressions that took decades to complete. ${ }^{52}$

Some recent studies also demonstrate that in the struggle over blueprints for a new beginning the ideal of a chastened but whole nation could not be realized. On the one hand, those conservative thinkers who despised Nazi populism sought to salvage older regional, religious, or humanistic traditions, which in their perception remained relatively undamaged. On the other hand, various antifascist groups tried to chart an independent German path toward democratic socialism, which would bring about political freedom and social equality. In the West, leftist intellectuals such as Walter Dirks and Eugen Kogon strove to find a "third way" between the camps of the Cold War, while in the East, Ernst Bloch and Hans Mayer tried to define what a democratic socialism might be like without Stalinist distortions. Due to the pressure of the occupation authorities who wanted to retain control over a German revival, the western radicals had to tone down their socialist aspirations, whereas their eastern counterparts eventually fled to the Federal Republic to preserve their freedom of thought. ${ }^{53}$ Further research is needed to establish what envisioned alternatives existed in the immediate postwar period and how they were ultimately channeled into two competing successor states.

The comparative and transnational orientation of current scholarship finally promises to resolve the controversy over German exceptionalism as well. Ironically, the postwar transition ended the classically negative Sonderweg of repudiating western values, but at the same time it also continued a postfascist difference in contrition. Elaborated by émigré scholars and taken over by a younger generation of critical historians in Germany, the thesis of a German deviation from the main course of western development contributed greatly to the liberalization of the intellectual atmosphere of the Federal Republic. It also provided a social science-based alternative to the Marxist class determinism of East German scholarship. ${ }^{54}$ But during the last decades, fresh work has eroded the credibility of the western standard of humanity by pointing to its practical failures in imperialism, racism, slavery, exploitation, and the like. In the grand pattern of modernization, the disastrous German embrace of Nazism fit squarely between the western development of market democracy and the eastern defense of authoritarianism. Clearly, with the defeat of the Third Reich, that murderous trajectory has come to an end. But the end of the war has also inaugurated a positive turn that has become an exemplary success story of redemption. ${ }^{55}$

University of North Carolina at Chapel Hill and University of Munich

\footnotetext{
${ }^{52}$ Gilad Margalit, Guilt, Suffering and Memory: Germany Remembers Its Dead of World War Two (Bloomington: Indiana University Press, 2010).

${ }^{53}$ Sean A. Forner, German Intellectuals and the Challenge of Democratic Renewal: Culture and Politics after 1945 (Cambridge: Cambridge University Press, 2014).

${ }^{54}$ Philipp Stelzel, History After Hitler: A Transatlantic Enterprise (Philadelphia: University of Pennsylvania Press, 2018).

${ }^{55}$ Konrad H. Jarausch, "Encounters with Modernity: The German Search for Alternatives in the Twentieth Century," in Oxford Handbook of German Politics, ed. Klaus Larres et al. (Oxford: Oxford University Press, forthcoming).
} 